\title{
Occurrence of Cosmarium species in Khadakpurna reservoir, Buldana district - Maharashtra, India
}

\author{
Mhaske T. K.* and Talwankar D. S. \\ Department of Botany, G. S. Science, Arts and Commerce College, Khamgaon, Dist. - Buldana, State - Maharashtra, India.
}

Publication history: Received on 15 November 2018; revised on 23 November 2018; accepted on 26 November 2018

Article DOI: https://doi.org/10.30574/gscbps.2018.5.3.0136

\begin{abstract}
The present investigation deals with the study of genus Cosmarium from Khadakpurna reservoir, It is constructed on Khadakpurna River of Godavari basin near Garkhed village, Deulgaon Raja tehsil in Buldana district, Maharashtra, India. During this study period twelve different species of Cosmarium has been described viz. 1. Cosmarium pygmaeum Archer, 2. Cosmarium portianum Arc. var. nephroideum Witter., 3. Cosmarium reniforme (Ralfs) Arch., 4. Cosmarium subprotumidum Nordst. var. gregorii Roy et Biss., 5. Cosmarium polygonum (Naeg.) Arch., 6. Cosmarium hammeri Reinsch var. Schmidlei Gronblad et Scott, 7. Cosmarium regnellii Wille, 8. Cosmarium lundellii Delp. var. ellipticum W. et G.S. West, 9. Cosmarium awadhense Prasad et Mehrotra, 10. Cosmarium undulatum Corda ex Ralfs var. minutum Wittr. Forma Suxena et Venkateswarlu. 11. Cosmarium calcareum Witter. 12. Cosmarium furcatospermum W. et G.S. West. All these taxa are reported first time from the reservoir. Such species occurrence in freshwater, hence these water body is indicated oligotrophic or some cases mesotrophic also and it is useful for irrigation, fisheries and with normal treatment it is useful for drinking purposes.
\end{abstract}

Keywords: Cosmarium species; Morphology; Khadakpurna reservoir

\section{Introduction}

Desmids occur exclusively in fresh water particularly in standing water such as ponds, lakes or shallow pools. The highest desmids diversity is found in mesotrophic, slightly acidic to slightly alkaline water bodies like moorland pools, peat, pits fen hollows [1, 2]. The genus Cosmarium belongs to Placoderm desmid [3]. It is free floating, occurs in fresh water ponds. Usually it occurs abundantly in mucilaginous masses along the walls of reservoirs in winter. The plant body consists of a small, flat cell. Length of the cell is one and half times greater than the breath. The cells are deeply divided in the middle by a short isthmus that contain nucleus. Each semicell has at least one central chloroplast (usually 2 or 4) with pyrenoids. In this complex genus the cells are much variable. All are constricted in the middle leading to its bi-lobed appearance [4]. More members of algal species can indicate water pollution and such study of assessing the quality of water as a part of investigation of algal diversity of Khadakpurna reservoir.

\section{Material and methods}

Water samples were collected from four different locations L-1 Takarkhed, L-2 Garkheda, L-3 Singaon Jha and L-4 Gavhan regularly at monthly intervals using clean sterilized plastic bottles. Samples of fresh water algae were collected with the help of phytoplankton net mesh and preserved in 4\% Formalin. Khadakpurna Reservoir is constructed on Khadakpurna River of Godavari basin near Garkhed village, Deulgaon Raja Tehsil in Buldana District, State Maharashtra, India. It is situated at $20^{\circ} 9^{\prime} 30^{\prime \prime} \mathrm{N}$ and $76^{\circ} 4^{\prime} 30^{\prime \prime} \mathrm{E}$, only $60 \mathrm{~km}$ away from district place. The dam is about $2160 \mathrm{~meters}$ in length with catchment area of $5133.18 \mathrm{~km}^{2}$. The project is having 160.606 Million cubic meters (mcum) capacity of

\footnotetext{
${ }^{*}$ Corresponding author

E-mail address: tusharmhaske.2010@gmail.com
} 
water storage, which includes 93.404 Million cubic meters live, and 67.202 Million cubic meters dead water stocks. Collected algal sample were studied in department of Botany G.S. College, Khamgaon, District Buldana (M.S.).

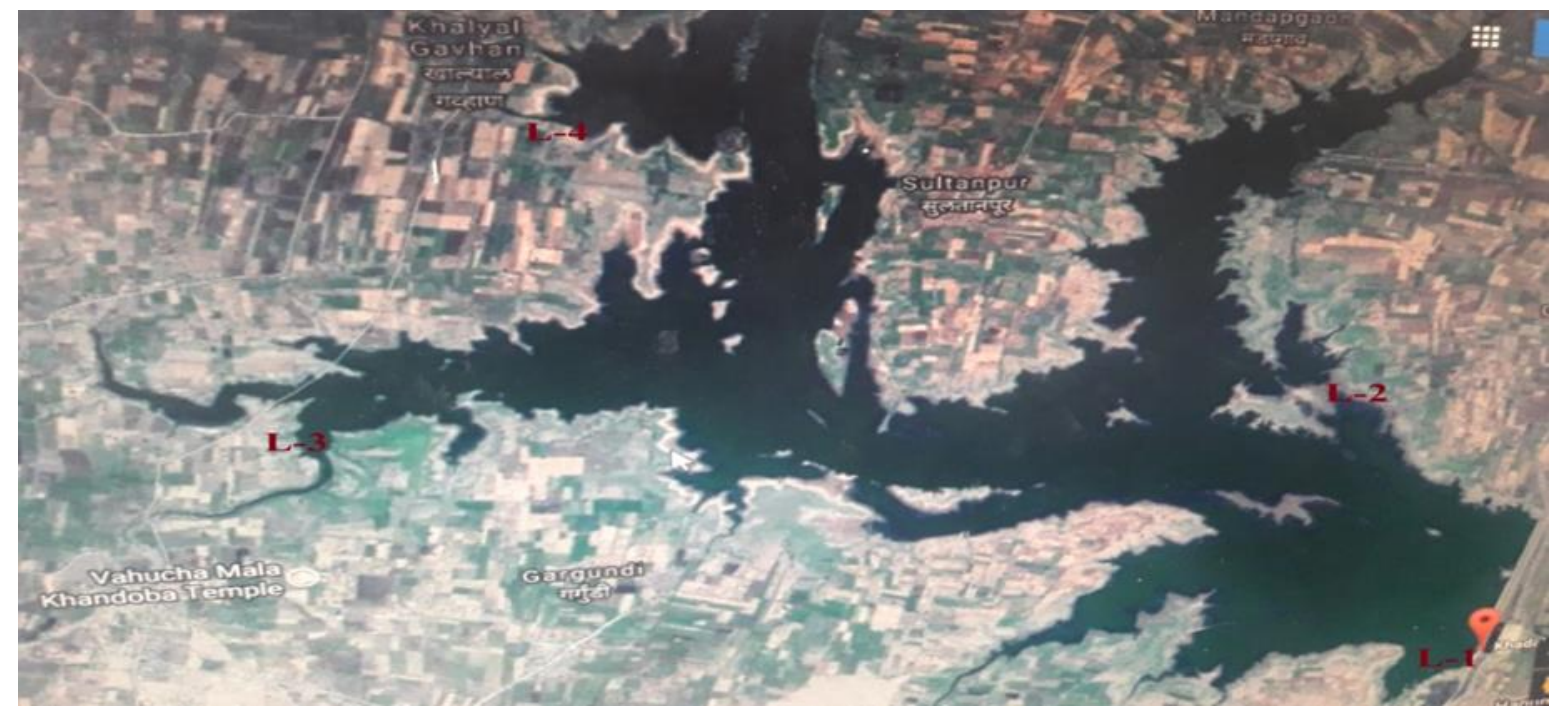

Figure 1 Topographic map showing location of Khadakpurna reservoir, Deulgaon Raja, District - Buldana, Maharashtra

\section{Results and discussion}

The taxonomic study of the collected specimens revealed the presence of 12 of the Placoderm desmid genus Cosmarium from Khadakpurna reservoir were observed which are described as follows.

\subsection{Cosmarium pygmaeum Archer}

Cell very small, a little longer than broad, deeply constricted, sinus narrowly linear; semicells oblong hexagonal, basal and apical angle sharp, apex widely truncate with straight margin, centre of each semicell with a faint protuberance; cell wall smooth. Cell $13 \mu \mathrm{m}$ long, lat. Cell $9 \mu \mathrm{m}$, lat. isthmus $4 \mu \mathrm{m}$ broad [5].

Location - Takarkhed, Garkheda, Singaon Jha and Ghavan.

\subsection{Cosmarium portianum Arc. var. nephroideum Witter.}

Cells small, about 1-3 times longer than broad, deeply constricted, sinus gradually opening from a rounded extremity, isthmus slightly elongated; semicells subreniform and granulate, granules rounded and evenly disposed in indistinct vertical series, visible margin of each semicell; with an axile chloroplast and a pyrenoid. Cell $21.5 \mu \mathrm{m}$ long, lat. cell 15.5 $\mu \mathrm{m}$, lat. isthmus $6 \mu \mathrm{m}$ broad [5].

Location - Garkheda, Singaon Jha and Ghavan.

\subsection{Cosmarium reniforme (Ralfs) Arch.}

Cells of medium size, slightly longer than broad, constriction deep, sinus narrow and linear with widely dilated extremity; semicells reniform; cell wall granulate, granules fairly regular, horizontal and in indistinct vertical series; chloroplast axile with 2 pyrenoids in each semicell. Cell $42 \mu \mathrm{m}$ long, lat. cell $32 \mu \mathrm{m}$, lat. isthmus $12 \mu \mathrm{m}$ long [5].

Location - Takarkhed, Gavhan.

\subsection{Cosmarium subprotumidum Nordst. var. gregori Roy et Biss.}

Cell small, a little longer than broad, sinus narrowly linear; semicells trapiziform, upper half narrowed to broadly truncate apex, sides with 3 faintly bigranulate crenations and apex with 3-4 slight undulation; cell wall with somewhat radially arranged granules within the margin, generally in pair above but single further away, center with tumour above 
the isthmus, consisting of relatively larger granules disposed in irregular vertical series; chloroplast axile with one pyrenoid in each semicell. Cell $28 \mu \mathrm{m}$ long, lat. cell $21 \mu \mathrm{m}$ long, lat. isthmus $4.5 \mu \mathrm{m}$ long [5].

Location - Singaon Jha and Gavhan.

\subsection{Cosmarium polygonum (Naeg.) Arch.}

Cell small, slightly longer than broad, deeply constricted, sinus narrow; semicells broadly hexagonal, angles rounded, lateral angles slightly pronounced, sides and apex faintly retuse; cell wall smooth. Cell $19 \mu \mathrm{m}$ long, lat. cell $15 \mu \mathrm{m}$ long, lat. isthmus $2.5 \mu \mathrm{m}$ long [5].

Location - Garkheda and Gavhan.

\subsection{Cosmarium hammeri Reinsch var. Schmidlei Gronblad et Scott.}

Cell small, about 1.5 times longer than broad, sub-hexagonal, deeply constricted sinus narrowly linear with dilated apex; semicells with upper part of lateral margins converging and retuse, apices faintly retuse with rounded angles; cell wall thick and smooth; top view elliptical. Cell $35.8 \mu \mathrm{m}$ long, lat. cell $23 \mu \mathrm{m}$ long, lat. isthmus $4.5 \mu \mathrm{m}$ long [5].

Location- Singaon Jha.

\subsection{Cosmarium regnellii Wille}

Cell very small, a little longer than broad deeply constricted, sinus narrow with slightly dilated extremity; semicells subhexagonal, basal angles more or less sub-rectangular, sides parallel, upper angles broad and oblique, apex truncate and straight; cell wall smooth; each semicell with an axile chloroplast and one pyrenoid. Cell $11 \mu \mathrm{m}$ long, lat. cell $8.6 \mu \mathrm{m}$ long, lat. isthmus $2.5 \mu \mathrm{m}$ long [5].

Location - SingaonJha and Gavhan.

\subsection{Cosmarium Iundellii Delp. var. ellipticum W. et G.S. West}

Cell smaller specific with a deep constriction and closed sinus; semicells sub-semicircular with relatively broader and rounded apices; cell wall minutely punctate. Cell $35.5 \mu \mathrm{m}$ long, lat. cell $32.5 \mu \mathrm{m}$ long, lat. isthmus $10 \mu \mathrm{m}$ long [5].

Location - Takarkhed, Garkheda, Singaon Jha and Ghavan.

\subsection{Cosmarium awadhense Prasad et Mehrotra}

Cell small, a little longer than broad, deeply constricted, sinus narrowly linear with a dilated extremity semicells subcircular, cell apices truncate and flat with straight margin, sides with 3-4 crenations without granules; cell wall smooth. Cell $17.5 \mu \mathrm{m}$ long, lat. cell $13.6 \mu \mathrm{m}$ long, lat. isthmus $4.5 \mu \mathrm{m}$ long [5].

Location - Singaon Jha and Gavhan.

\subsection{Cosmarium undulatum Corda ex Ralfs var. minutum Wittr. forma Suxena et Venkateswarlu.}

Cell small, quadrate-elliptic, slightly longer than broad, deeply constricted, sinus narrow with dilated extremity; semicells sub-semicircular with 7-8 shallow undulation, apex slightly retuse; cell wall smooth; top view elliptic; chloroplast axile with one pyrenoid in each semicell. Cell $21 \mu \mathrm{m}$ long, lat. cell $14.6 \mu \mathrm{m}$ long, lat. isthmus $2.5 \mu \mathrm{m}$ long [5].

Location - Singaon Jha.

\subsection{Cosmarium calcareum Witter.}

Cells small, almost as long as broad, deeply constricted, sinus narrowly linear; semicells somewhat trapizoid, basal angles sub rectangular, sides 4 - crenate, apex truncate with 6-7 faint and minute crenations; cell wall with minute granules and a small granulate tumour in the centre; top view narrowly elliptic. Cell $17 \mu \mathrm{m}$ long, lat. cell $14 \mu \mathrm{m}$, lat. isthmus $3.5 \mu \mathrm{m}$ long [5].

Location - Takarkhed and Gavhan. 


\subsection{Cosmarium furcatospermum W. et G.S. West.}

Cells rather small, slightly longer than broad, deeply constricted, sinus linear; semicells truncate, sub-semicircular, lateral margins 4-5 crenately-granulate, apex broadly truncate and 5-6 undulate with 3 series of small granules within the whole margin, central region smooth; top view oblong-elliptic; each semicell with an axile chloroplast containing a large pyrenoid in the centre. Cell $29 \mu \mathrm{m}$ long, lat. cell $25 \mu \mathrm{m}$ long, lat. isthmus $7.5 \mu \mathrm{m}$ long [5].

Location - Gavhan.

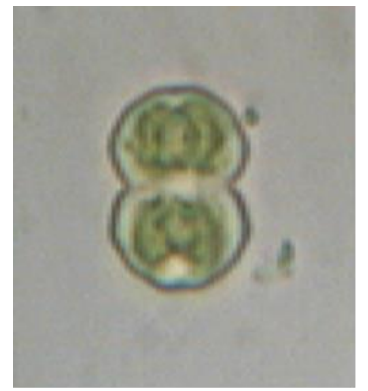

a

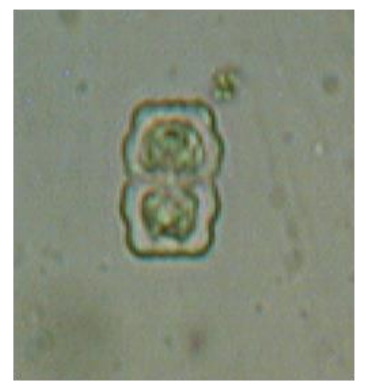

e

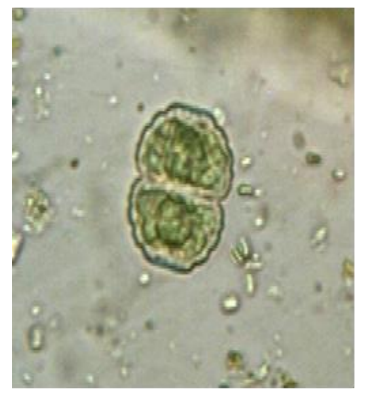

i

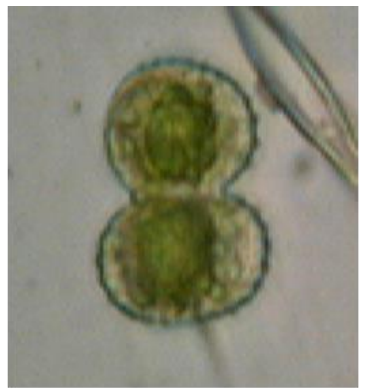

b

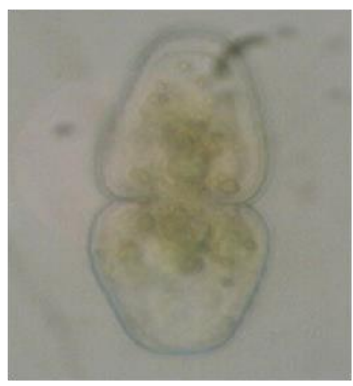

f

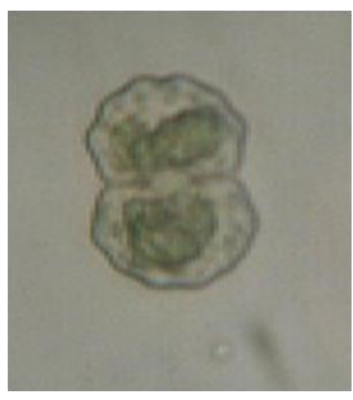

j

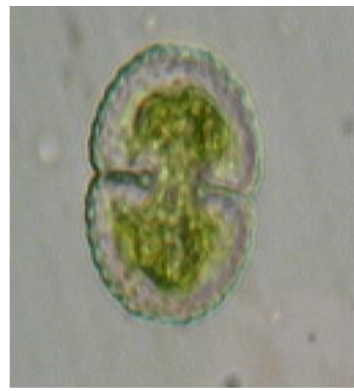

C

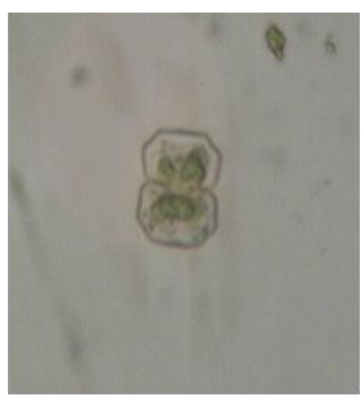

g

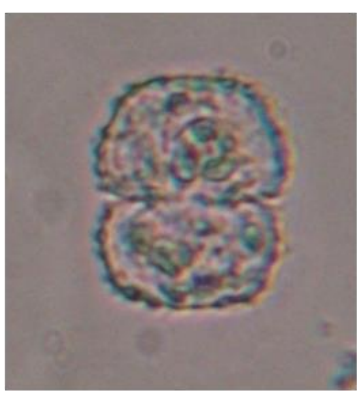

$\mathrm{k}$

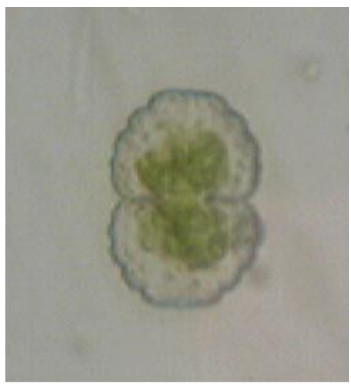

d

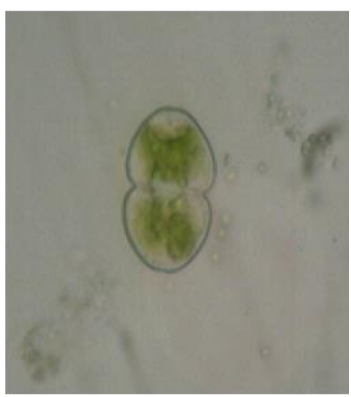

h

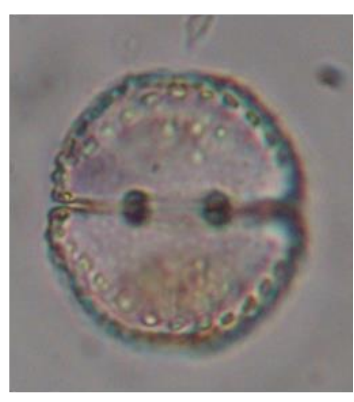

I

Figure 2 Twelve Cosmarium species from Khadakpurna reservoir of Buldhana district (a- C. pygmaeum, b- $C$. portianum, c- C. reniforme, d- C. subprotumidum, e- C. polygonum, f- C. hammeri, g- C. regnellii, h- C. lundellii, i- $C$. awadhense, j- C. undulatum, k- C. calcareum, l- C. furcatospermum)

\section{Conclusion}

Cosmarium species were identified on the basis of morphology and cell measurement. Predominantly species occurred during winter season, gradually occurrence decreased in summer season and the density of Cosmarium is very low in rainy season which may be due to contamination of agriculture, domestic waste, organic and inorganic effluents. Most of the species in present study found at L-3 and L-4 site because it is not much deeper. 


\section{Compliance with ethical standards}

\section{Acknowledgments}

I would like to thanks Head, Department of Botany, G. S. Science, Arts and Commerce College, Khamgaon, Dist. - Buldana, (M.S) for providing laboratory facilities.

\section{Disclosure of conflict of interest}

The authors have declared that no conflict of interest.

\section{References}

[1] Coesel PF. (1982). Structural characteristics and adaptations of desmid communities. Journal of Ecology, 70, 163177.

[2] Coesel PF and Meesters J. (2007). Desmids of the lowlands, Mesotaeniaceae and Desmidiaceae of the European Lowlands. KNNV Publishing, Zeist, The Netherlands, 351.

[3] Felisberto SA and Rodrigues L. (2004). Periphytic Desmids in Corumba Reservoir, Goias, Brazil. Brazil Journal of Biology, 64(1), 141-150.

[4] Guiry MD, John DM, Rindi F, and McCarty YK. (2007). New survey of Clare Island. The Freshwater and Terrestrial Algae Royal Irish Academy, 6, 31-7.

[5] Prasad BN and Misra PK (1992). Fresh water algal flora of Andman and Nicobar Island, Vol. II. Bishen Singh Mahendra Pal Singh, Dehra Dun.

\section{How to cite this article}

Mhaske TK and Talwankar DS. (2018). Occurrence of Cosmarium species in Khadakpurna reservoir, Buldana district Maharashtra, India. GSC Biological and Pharmaceutical Sciences, 5(3), 20-24. 